\title{
Apoptosis and Expression of the Bcl-2 Family of Proteins and P53 in Human Pancreatic Ductal Adenocarcinoma
}

\author{
Dong Chen $^{\mathrm{a}}$ Xuefeng Zheng ${ }^{\mathrm{a}}$ Dalu Kang ${ }^{\mathrm{b}}$ Bomin Yan $^{\mathrm{b}}$ Xiaoyi Liu $^{\mathrm{b}}$ \\ Yuan Gao ${ }^{c}$ Kejun Zhang ${ }^{a}$ \\ a Department of General Surgery and b Laboratory Department, Affiliated Hospital of Medical College, QingDao \\ University, QingDao, and ' Department of Hepatobiliary Surgery, Key Laboratory of Cancer Prevention and Therapy, \\ Tianjin Medical University Cancer Institute and Hospital, Tianjin, China
}

\section{Key Words}

Pancreatic ductal adenocarcinoma $\cdot$ Apoptosis $\cdot$ P53 $\cdot$ Bcl-2 protein family

\begin{abstract}
Objective: The purpose of this study was to clarify the association between P53 and the Bcl-2 family (Bcl-2, Bax, Bcl-xL, $\mathrm{Bcl}-\mathrm{xS}$ ) expression and apoptosis in pancreatic ductal adenocarcinoma (PDAC). Subjects and Methods: A total of 70 patients with PDAC were studied. The expression of P53 protein in PDAC was assessed using the immunohistochemical method, which categorized the PDAC patients into two groups: group 1: 36 cases with immunonegative P53(-), and group 2: 34 cases with immunopositive P53(+). The expression of $\mathrm{BCl}-2, \mathrm{Bax}, \mathrm{BCl}-\mathrm{xL}$, and $\mathrm{Bcl}-\mathrm{xS}$ in the 70 PDAC cases was detected by immunohistochemical and Western blotting methods. The apoptotic index (Al) was also measured in these samples by the terminal deoxynucleotidyl transferasemediated dUTP-biotin nick end labeling (TUNEL) method. The relation between $\mathrm{P} 53$ and the $\mathrm{BCl}-2$ protein family and apoptosis was then evaluated. Results: $\mathrm{Bcl}-2$ and $\mathrm{Bcl}-\mathrm{xS}$ expression was significantly associated with P53 $(p<0.05)$. No clear associations were found among P53, Bax and Bcl-xL expression $(p>0.05)$. The Al of groups 1 and 2 was $12.1 \pm 2.47$
\end{abstract}

and $8.1 \pm 1.48$, respectively $(p=0.023)$. There was no relationship between $\mathrm{Al}$ and $\mathrm{BCl}-2, \mathrm{Bax}, \mathrm{BCl}-\mathrm{xL}$ and $\mathrm{BCl}-\mathrm{xS}$ expression ( $p>0.05$, respectively). $B c l-2 / B a x$ ratio was significantly associated with $\mathrm{Al}(\mathrm{p}<0.01)$. Conclusion: $\mathrm{BCl}-2$ and $\mathrm{BCl}-\mathrm{xS}$ represent significant anti- and proapoptotic proteins, respectively, modulated through a P53-dependent pathway in PDAC, and P53 modulated apoptosis mainly through Bcl-2/ Bax ratio.

Copyright $\odot 2011$ S. Karger AG, Basel

\section{Introduction}

Apoptosis has been accepted as a fundamental component in the pathogenesis of cancer. The origin of cancer involves deregulated cellular proliferation and the suppression of apoptotic processes, ultimately leading to tumor establishment and growth [1]. A major challenge in oncology is the development of chemoresistance. This often occurs as cancer progresses and malignant cells acquire mechanisms to resist insults that would normally induce apoptosis [2]. Factors affecting the apoptotic function by any mechanism may also interfere with the prognosis of cancer patients. 
Pancreatic cancer, particularly pancreatic ductal adenocarcinoma, which is a malignancy with an extremely poor prognosis, is still a highly therapy-refractory disease [3-6]. Among the mechanisms by which pancreatic ductal adenocarcinoma cells could escape any nonsurgical therapy, antiapoptotic protection seems to be the most relevant one [6-8]. The family of Bcl-2-related proteins constitutes one of the most biologically relevant classes of apoptosis regulatory gene products acting at the effect stage of apoptosis [9-12].

The Bcl-2 family is composed of death antagonists (Bcl-2, Bcl-xL, Bcl-w, Bfl-1, Brag-1, Mcl-1, and A1) and death agonists (Bax, Bak, Bcl-xS, Bad, Bid, Bik and Hrk) [11-13]. The ratio of death antagonists to agonists determines whether or not a cell will respond to an apoptosis signal [14]. The death-life rheostat is mediated, at least in part, by competitive dimerization between selective pairs of antagonists and agonists $[15,16]$. Furthermore, diverse effects of $\mathrm{P} 53$ on the transcription of the Bcl-2 protein family that regulate apoptosis substantially affect the biological aggressiveness of PADC $[17,18]$. The transcription of Bax, a proapoptotic member of the Bcl-2 family, is activated by wild-type $\mathrm{P} 53$, while $\mathrm{Bcl}-2$, which functions to prevent apoptosis, is transcriptionally repressed by wildtype P53 $[19,20]$. Nevertheless, the relationship between the Bcl-2 protein family and $\mathrm{P} 53$ remains unclear. In this study, we analyzed the relationship between P53 and Bcl2, Bax, Bcl-xL, Bcl-xS protein expression and apoptosis.

\section{Subjects and Methods}

\section{Tissue Samples}

Pancreatic adenocarcinoma (PADC) tissues were obtained consecutively from 70 patients who underwent surgery for pancreatic adenocarcinoma (ordinary ductal carcinoma) at the Department of General Surgery, Qingdao University from 2005 through 2010. Each tissue sample was bisected: half of each sample was processed for routine histopathologic examination and immunohistochemical study; the other half was frozen immediately in liquid nitrogen and stored at $-80^{\circ} \mathrm{C}$ for Western blot study. Informed written consent was obtained from each patient prior to surgery. Immunohistochemical study was performed for P53 and the Bcl-2 protein family on serial paraffin sections and the apoptosis index (AI) evaluated by the terminal deoxynucleotidyl transferase-mediated dUTP-biotin nick end labeling (TUNEL) method. Western blot analysis was performed for P53 and the Bcl-2 protein family on frozen tissues.

\section{Immunohistochemical Staining}

Tumor tissue sections were cut (thickness $4 \mu \mathrm{m}$ ), placed on slides coated with $0.05 \%$ poly-L-lysine hydrobromide, and toasted at $58^{\circ} \mathrm{C}$ for $24 \mathrm{~h}$. The sections were dewaxed with xylene, dehydrated through a series of alcohol solutions $(95,85,75 \%)$ for $2 \mathrm{~min}$, and then incubated in 3\% (v/v) hydrogen peroxide in absolute methanol for 20 min to quench endogenous peroxidase activity. After brief washing with distilled water, the tissue sections were processed in $4 \mathrm{mM}$ citrate buffer ( $\mathrm{pH}$ 6.0) and heated to $120^{\circ} \mathrm{C}$ in an autoclave for $10 \mathrm{~min}$ for antigen retrieval. Slides were allowed to cool at room temperature for $20 \mathrm{~min}$ and then rinsed with phosphate-buffered saline (PBS). To inhibit nonspecific binding activity, slides were incubated with blocking serum at room temperature for $30 \mathrm{~min}$. Sections were then incubated with primary monoclonal antibody against $\mathrm{P} 53, \mathrm{Bcl}-2, \mathrm{Bax}, \mathrm{Bcl}-\mathrm{xL}$ and $\mathrm{Bcl}-\mathrm{xS}$, respectively at 1:400-1:1,000 (Santa Cruz Biotechnology), at $4^{\circ} \mathrm{C}$. The sections were then incubated with biotinylated anti-mouse immunoglobulins for $30 \mathrm{~min}$ at room temperature, washed in PBS. 3,3'-Diaminobenzidine tetrahydrochloride, which was used as the color reagent, and hematoxylin as a counterstain. Immunostaining was evaluated by 2 independent pathologists to validate the diagnosis.

\section{Evaluation of Immunohistochemistry Results}

Immunohistochemical staining of P53 was defined as a detectable immunoreaction in the nucleus. Only nuclear staining was considered to be immunohistochemically positive for P53. The staining intensity of the positive cells was classified into the following grades [20]: negative immunoreactive staining intensity $(-)$ : positive cells less than $10 \%$; positive immunoreactive staining intensity (+): positive cells more than $10 \%$. Immunohistochemical staining of Bcl-2, Bax, Bcl-xL and Bcl-xS was defined as detectable immunoreaction in cytoplasm. The amounts of immunopositive cells were estimated semiquantitatively: grade ' + ' corresponds to $5-10 \%$, grade ' ++ ' to $10-50 \%$, and grade ' +++ ' to more than $50 \%$ positive cells [21]. All series included positive and negative controls. The results of control staining were satisfactory.

\section{Western Blotting Analysis}

Small sections of frozen tissue were cut and homogenized in $200 \mu \mathrm{l}$ of ice-cold lysis buffer. After incubation for $30 \mathrm{~min}$ on ice, the samples were centrifuged at $14,000 \mathrm{rpm}$, then at $4{ }^{\circ} \mathrm{C}$ for $20 \mathrm{~min}$ and the supernatant was transferred to a new tube. Total protein was measured with a Bio-Rad Bradford kit, then $30 \mu \mathrm{g}$ of total protein was run on a $12 \%$ SDS-polyacrylamide gel and transferred to a nitrocellulose membrane that was blocked with nonfat dry milk in Tris-buffered saline overnight at $4^{\circ} \mathrm{C}$. The membrane was then probed with a primary antibody, washed several times with Tween-20 (0.3\%), and incubated with a horseradish peroxidase-conjugated secondary antibody. Finally, the membrane was washed with an enhanced chemiluminescence system. The primary antibodies used were P53, Bcl-2, Bax, Bcl-xL and Bcl-xS (1:100-1:200, Santa Cruz Biotechnology). As a control for sample loading, the blot was stripped and reprobed with antiglyceraldehyde-3-phosphate dehydrogenase (GAPDH) polyclonal antibody. Densitometric quantification of the autoradiographs was performed with a Bio-Rad/GS 700 imaging densitometer. Protein levels in tumor tissues were quantified and the ratio of protein to GAPDH was defined as the protein expression.

\section{TUNEL Analysis}

DNA fragmentation characteristics of the apoptosis of the specimen were monitored by TUNEL staining using an Apoptag peroxidase in situ apoptosis detection kit by following the manufacturer's instructions. Briefly, after deparaffinization and incu- 
bation with $20 \mu \mathrm{g} / \mathrm{ml}$ of proteinase $\mathrm{K}$ for $15 \mathrm{~min}$ at room temperature, the sections were rinsed with PBS once, then rinsed with deionized distilled water 3 times at 5 -min intervals. The sections were incubated with $3 \% \mathrm{H}_{2} \mathrm{O}_{2}(50 \mu \mathrm{l} /$ section $)$ in methanol for $10 \mathrm{~min}$ at room temperature and the slides were rinsed 3 times at 5 -min intervals with deionized distilled water. The slides were incubated in a permeabilization solution $(50 \mu \mathrm{l} /$ section $)$ for $3 \mathrm{~min}$ at room temperature. After washing 3 times at 5 -min intervals in deionized distilled water, the sections were incubated in a TdT buffer containing TdT $(0.6 \mu \mathrm{l})$ and fluorescein-deoxy-UTP (dUTP $1.4 \mu \mathrm{l}$ ) for $1 \mathrm{~h}$ at $37^{\circ} \mathrm{C}$ in a humidified chamber. The coverslips were washed in PBS 3 times at 3-min intervals and incubated with antibody conjugated to peroxidase for $30 \mathrm{~min}$ at $37^{\circ} \mathrm{C}$ in a humidified chamber. The coverslips were incubated with avidin-HRP $(50 \mu \mathrm{l})$ for $60 \mathrm{~min}$ at $37^{\circ} \mathrm{C}$ in a humidified chamber and washed in PBS 3 times at 3-min intervals, then stained with diaminobenzidine and counterstained as above. A total of 500 cells were counted in each specimen. The apoptotic index was defined as follows: apoptotic index $(\%)=100 \times$ apoptotic cells/total cells. The tumor specimens were stratified according to TUNEL staining in $<10$ or $>10 \%$ stained cells.

\section{Statistical Analysis}

All continuous variables are expressed as mean \pm SD. Statistical analysis was done by using the $\chi^{2}$ test or Fisher's test for qualitative data and Student's $t$ test for quantitative data; $p<0.05$ was considered statistically significant.

\section{Results}

\section{Immunohistochemical Analysis}

The immunostaining results are presented in table 1. Of the 70 samples, P53(+) was detected in 34 (48.6\%) and P53(-) in 36 (51.4\%). In the P53(-) samples, Bcl-xS and Bax showed strong immunoreactivity $(++/+++)$, and Bcl2 and Bcl-xL showed weak immunoreactivity (+). In P53(+) samples, Bcl-xS and Bax showed weak immunoreactivity (+), however, Bcl-2 and Bcl-xL showed strong immunoreactivity $(++/+++)$. A significant association was found between P53 accumulation and down-regulation of $\mathrm{Bcl}-\mathrm{xS}(\mathrm{p}=0.003)$. A highly significant association was found between P53 accumulation and up-regulation of $\mathrm{Bcl}-2(\mathrm{p}=0.026)$. However, no significant association between $\mathrm{P} 53$ accumulation and Bcl-xL, Bax was shown ( $\mathrm{p}>$ 0.05). The representative expression of $\mathrm{P} 53, \mathrm{Bcl}-2, \mathrm{Bcl}-\mathrm{xL}$, $\mathrm{Bcl}-\mathrm{xS}$ and Bax is shown in figure 1 .

\section{Western Blot Analysis}

Western blot for $\mathrm{P} 53$ and the Bcl-2 protein family (Bcl2 , Bax, Bcl-xL, and Bcl-xS) was detected in the 70 pancreatic cancer cases. The relative expression levels of Bcl-2, $\mathrm{Bax}, \mathrm{Bcl}-\mathrm{xL}$ and $\mathrm{Bcl}-\mathrm{xS}$ protein are shown in table 2. A highly significant association between P53 with Bcl-xS
Table 1. Protein accumulation of $\mathrm{P} 53$ relative to other proteins in pancreatic cancer

\begin{tabular}{llllll}
\hline Protein & $\begin{array}{l}\text { Staining } \\
\text { intensity }\end{array}$ & $\mathrm{n}$ & $\begin{array}{l}\mathrm{P} 53(-) \\
(\mathrm{n}=36)\end{array}$ & $\begin{array}{l}\text { P53(+) } \\
(\mathrm{n}=34)\end{array}$ & $\mathrm{p}$ \\
\hline Bcl-2 & $0 /+$ & 41 & 28 & 13 & 0.026 \\
& $++/+++$ & 29 & 8 & 21 & \\
\hline Bcl-xS & $0 /+$ & 48 & 23 & 25 & 0.003 \\
& $++/+++$ & 22 & 13 & 9 & \\
\hline Bax & $0 /+$ & 49 & 22 & 27 & 0.145 \\
& $++/+++$ & 21 & 14 & 7 & \\
\hline Bcl-xL & $0 /+$ & 33 & 21 & 12 & 0.093 \\
& $++/+++$ & 37 & 15 & 22 & \\
\hline
\end{tabular}

Table 2. Correlation of expression of Bcl-2, Bax, Bcl-xL and Bcl-xS with P53

\begin{tabular}{lllll}
\hline & & Ratio $\geq 1$ & Ratio $<1$ & $p$ \\
\hline Bcl-2 & group 1 & 11 & 25 & 0.017 \\
& group 2 & 25 & 9 & \\
\hline Bax & group 1 & 23 & 13 & 0.173 \\
& group 2 & 18 & 16 & \\
\hline Bcl-2/Bax & group 1 & 10 & 26 & 0.028 \\
& group 2 & 22 & 12 & \\
\hline Bcl-xL & group 1 & 14 & 22 & 0.125 \\
& group 2 & 19 & 15 & 0.013 \\
\hline Bcl-xS & group 1 & 26 & 10 & \\
& group 2 & 11 & 23 & 0.146 \\
\hline Bcl-xL/Bcl-xS & group 1 & 13 & 23 & \\
& group 2 & 14 & 20 & \\
\hline
\end{tabular}

and $\mathrm{Bcl}-2$ expression was observed $(\mathrm{p}<0.05)$. No significant association between $\mathrm{P} 53$ and Bcl-xL, Bax expression was found ( $\mathrm{p}>0.05$ ). The $\mathrm{Bcl}-2 / \mathrm{Bax}$ ratio was remarkably up-regulated in group 2 , but was down-regulated in group $1(\mathrm{p}<0.05)$. The representative samples of the 70 pancreatic cancer cases are shown in figure 2 .

\section{Apoptosis Analysis}

The AI was $12.1 \pm 2.47$ and $8.1 \pm 1.48$ in groups 1 and 2 , respectively. A remarkable correlation was found between P53 expression and AI (fig. 3, p = 0.023). The relationship between AI and the expression of Bcl-2 family proteins is presented in table 3. No relationship was found between the expression of $\mathrm{Bcl}-2$, Bax, Bcl-xL, Bcl-xS and 

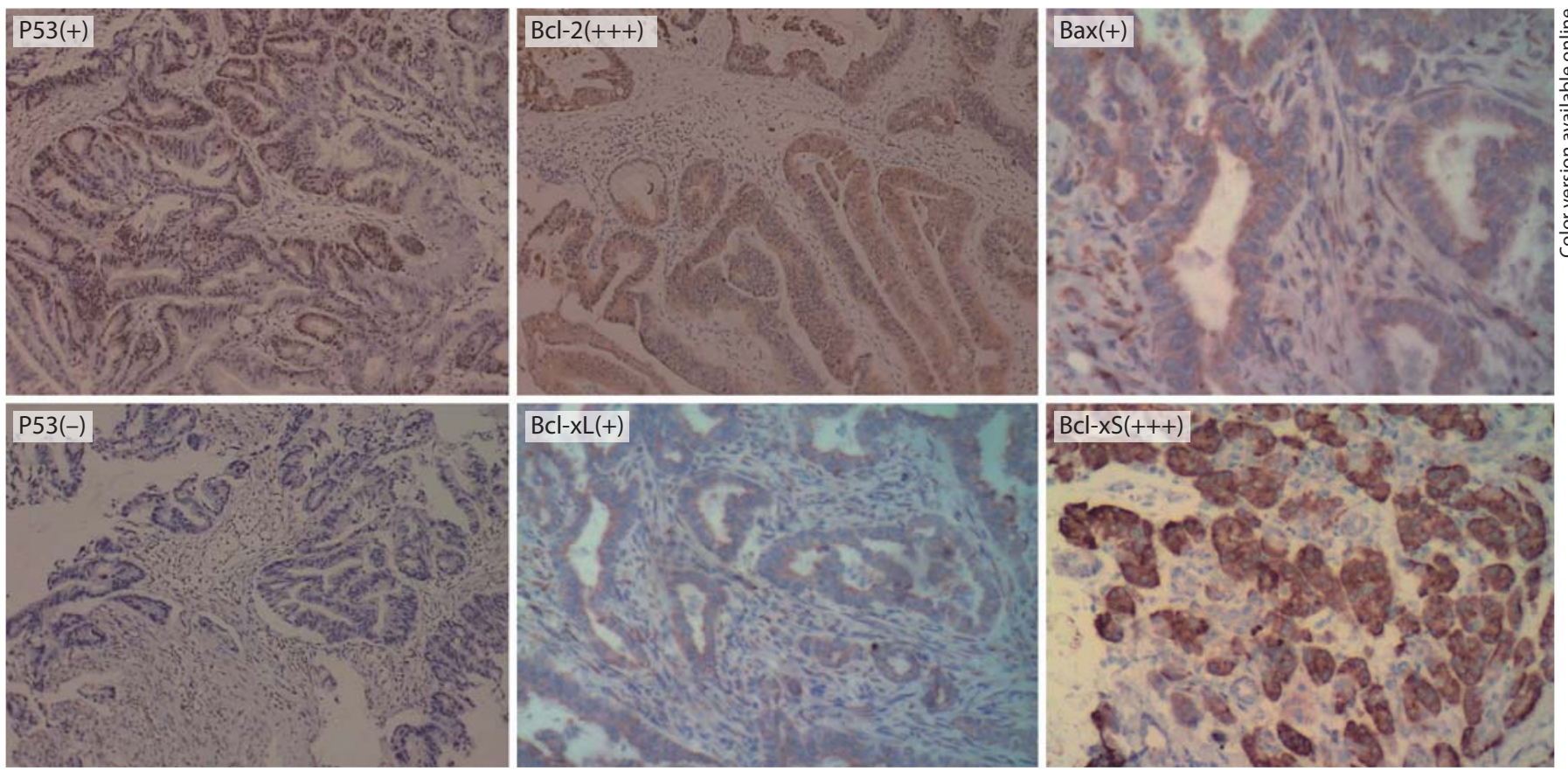

Fig. 1. Tumor tissue from pancreatic cancer showing immunoreactivity for $\mathrm{P} 53, \mathrm{Bcl}-2, \mathrm{Bax}, \mathrm{Bcl}-\mathrm{xL}$ and $\mathrm{Bcl}-\mathrm{xS}$ proteins. $\mathrm{P} 53$ protein immunoreactivity was seen in cell nuclei. Bcl-2, Bax, Bcl-xL and Bcl-xS protein expression was detected in the cytoplasm. Magnification $\times 100$.

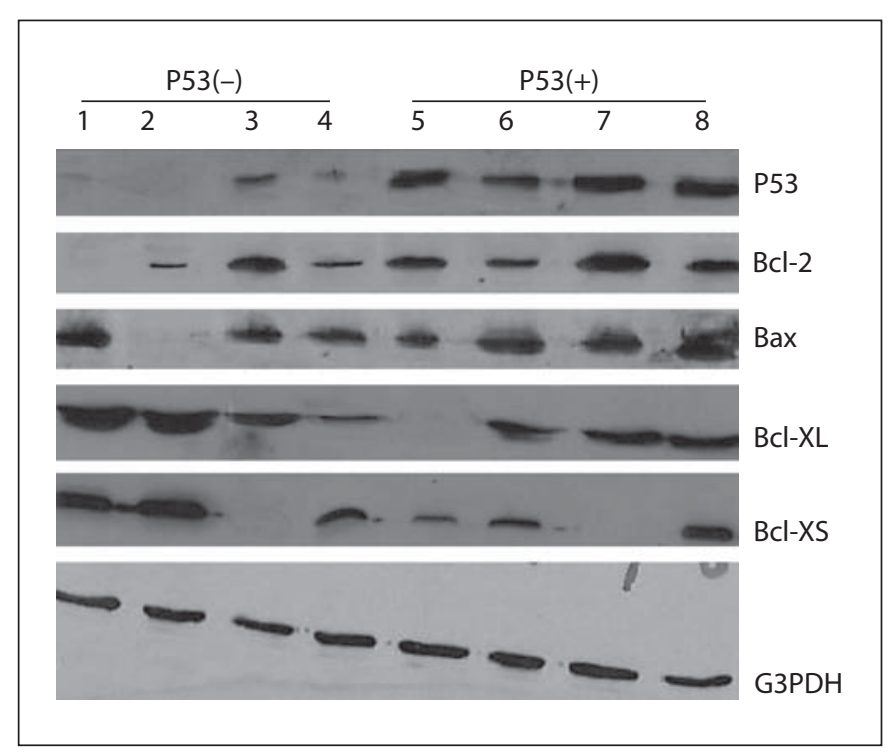

Fig. 2. Western blotting for P53, Bcl-2, Bax, Bcl-xL and Bcl-xS expression. Bcl-2 protein level was strikingly higher in P53(+) tissues $(\mathrm{p}<0.05)$, and $\mathrm{Bcl}-\mathrm{xS}$ protein level was strikingly higher in P53(-) tissues $(p<0.05)$. No significant association between P53 and $\mathrm{Bcl}-\mathrm{xL}$ and Bax expression was found ( $\mathrm{p}>0.05)$.
Table 3. Correlation of $\mathrm{Bcl}-2, \mathrm{Bax}, \mathrm{Bcl}-\mathrm{xL}$ and $\mathrm{Bcl}-\mathrm{xS}$ with $\mathrm{AI}$

\begin{tabular}{|c|c|c|c|c|}
\hline & & Cases & AI & $\mathrm{p}$ \\
\hline Bcl-2/GAPDH & $\begin{array}{l}\text { ratio } \geq 1 \\
\text { ratio }<1\end{array}$ & $\begin{array}{l}36 \\
34\end{array}$ & $\begin{array}{r}9.36 \pm 2.26 \\
11.54 \pm 2.54\end{array}$ & 0.063 \\
\hline $\mathrm{Bax} / \mathrm{GAPDH}$ & $\begin{array}{l}\text { ratio } \geq 1 \\
\text { ratio }<1\end{array}$ & $\begin{array}{l}41 \\
29\end{array}$ & $\begin{array}{r}10.89 \pm 3.82 \\
9.27 \pm 2.06\end{array}$ & 0.082 \\
\hline Bcl-xL/GAPDH & $\begin{array}{l}\text { ratio } \geq 1 \\
\text { ratio }<1\end{array}$ & $\begin{array}{l}33 \\
37\end{array}$ & $\begin{array}{l}10.67 \pm 3.21 \\
10.25 \pm 1.36\end{array}$ & 0.105 \\
\hline Bcl-xS/GAPDH & $\begin{array}{l}\text { ratio } \geq 1 \\
\text { ratio }<1\end{array}$ & $\begin{array}{l}37 \\
33\end{array}$ & $\begin{array}{l}10.23 \pm 2.66 \\
10.82 \pm 2.49\end{array}$ & 0.320 \\
\hline $\mathrm{Bcl}-2 / \mathrm{Bax}$ & $\begin{array}{l}\text { ratio } \geq 1 \\
\text { ratio }<1\end{array}$ & $\begin{array}{l}32 \\
38 \\
\end{array}$ & $\begin{array}{r}7.19 \pm 1.87 \\
13.02 \pm 3.45\end{array}$ & 0.004 \\
\hline Bcl-xL/Bcl-xS & $\begin{array}{l}\text { ratio } \geq 1 \\
\text { ratio }<1\end{array}$ & $\begin{array}{l}27 \\
43\end{array}$ & $\begin{array}{r}9.72 \pm 2.58 \\
11.51 \pm 3.19\end{array}$ & 0.163 \\
\hline
\end{tabular}


Fig. 3. Apoptosis detected by TUNEL. $\times 200$. TUNEL analysis was used to detect apoptosis in P53(+) and P53(-) groups. AI was remarkably increased in P53(-) groups $(\mathrm{p}<0.05)$.
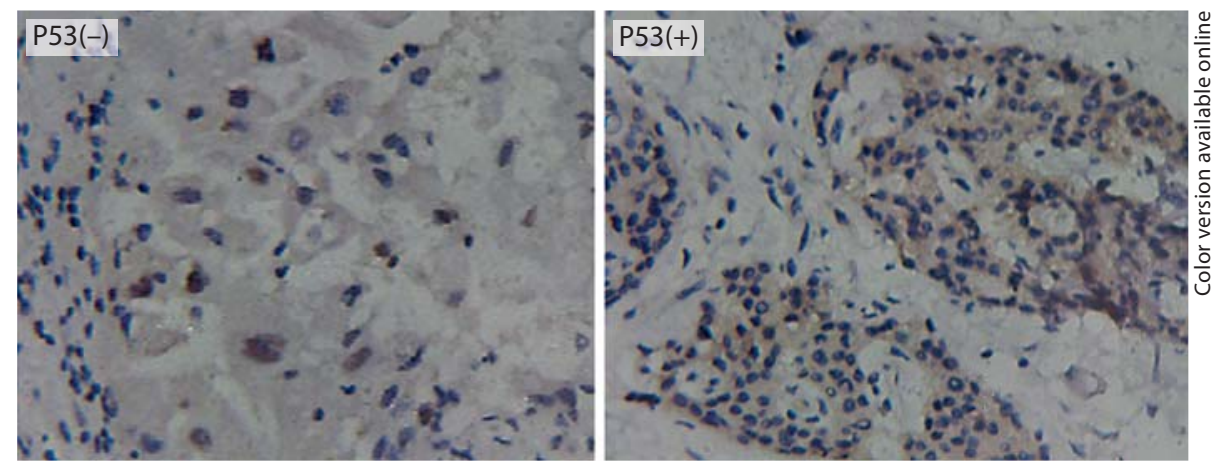

AI, respectively ( $p>0.05)$. However, AI was remarkably increased in the low Bcl-2/Bax ratio groups, and decreased in the high $\mathrm{Bcl}-2 / \mathrm{Bax}$ ratio group $(\mathrm{p}=0.012)$. No relationship was seen between $\mathrm{AI}$ and $\mathrm{Bcl}-\mathrm{xL} / \mathrm{Bcl}-\mathrm{xS}$ ratio $(\mathrm{p}>0.05)$. Representative pictures of apoptosis of PADC are shown in figure 3.

\section{Discussion}

Wild-type $\mathrm{P} 53$ protein functions as a transregulator of the genes involved in DNA synthesis, repair, and apoptosis. Because of its very short half-life and the minute amounts found in normal cells, wild-type P53 protein is almost undetectable by immunohistochemical staining [21-23]. However, P53 inactivated through mutations, deletions, or binding to other proteins results in a $\mathrm{P} 53$ protein accumulation that can be detected by immunohistochemistry [24, 25].

Apoptosis is known to be a gene-directed process and can be mediated through at least two pathways, which can be dependent upon or independent of the induction of P53 [26, 27]. However, P53 is required if programmed cell death is to be efficiently executed [26]. In this study, the findings of $48.6 \%$ of the PADC cases were immunopositive for P53, the apoptosis indexes of groups 1 and 2 were $12.1 \pm 2.47$ and $8.1 \pm 1.48$, respectively $(\mathrm{p}=$ $0.023)$; thus, the finding that AI was dependent on P53 in PADC confirmed previous reports [28, 29]. P53 promotes mitochondrial leakage by up-regulating Bax and downregulating $\mathrm{Bcl}-2$, two antagonistic proteins that insert into mitochondrial membranes to inhibit $(\mathrm{Bcl}-2)$ or facilitate ( $\mathrm{Bax}$ ) the opening of mitochondrial permeability transition pores [30]. Based on our results, Bcl-2 was remarkably overexpressed in group 2, possibly due to the absence of restraint of functional P53; Bcl-2 was under- expressed in the majority of group 1 cases through functional P53 inhibition. The ratio of antiapoptotic to proapoptotic protein expression, like $\mathrm{Bcl}-2$ to $\mathrm{Bax}$ and $\mathrm{Bcl}-\mathrm{xL}$ to Bax, represents a rheostat that determines a cell's life or death response to an apoptotic stimulus [31, 32].

In this study, Bax was unexpectedly overexpressed in a majority of the PADC cases, in both group 1 and group 2 . Accordingly, the $\mathrm{Bcl}-2 / \mathrm{Bax}$ ratio was remarkably elevated in PADC cases with immunopositive P53 compared to that of PADC cases with immunonegative P53. Again, Bcl$\mathrm{xL}$ was up-regulated in a majority of PADC cases with either immunopositive or immunonegative P53. Bcl-xS was remarkably down-regulated in PADCs with immunopositive P53 compared to those with immunonegative P53. Accordingly, the $\mathrm{Bcl}-\mathrm{xL} / \mathrm{Bcl}-\mathrm{xS}$ ratio was similarly up-regulated in PADCs with immunopositive P53 compared to that of PADC cases with immunonegative P53. In our study, there was no relationship between $\mathrm{AI}$ and the expression of $\mathrm{Bcl}-2$, Bax, Bcl-xL, Bcl-xS and Bcl-xL/Bcl-xS ratio alone ( $\mathrm{p}>0.05$, respectively), but AI was remarkably increased in the high $\mathrm{Bcl}-2 / \mathrm{Bax}$ ratio group, and decreased in the $\mathrm{Bcl}-2 / \mathrm{Bax}$ ratio group $(\mathrm{p}=0.012)$. This demonstrates that it is not individual apoptosis-related proteins, but the net effect of the antagonistic/agonistic proteins that determines the fate of the affected cells.

\section{Conclusion}

Taken together, Bcl-2 and Bcl-xS represented the most significant individual antiapoptotic and proapoptotic proteins, respectively, expressed in human pancreatic cancer in the current study, and the Bcl-2/Bax ratio was more deeply modulated by the P53-dependent pathway than was the $\mathrm{Bcl}-\mathrm{xL} / \mathrm{Bcl}-\mathrm{xS}$ ratio. P53 modulated apoptosis mainly through $\mathrm{Bcl}-2 / \mathrm{Bax}$ ratio. 


\section{References}

$>1$ Hunter AM, LaCasse EC, Korneluk RG: The inhibitors of apoptosis (IAPs) as cancer targets. Apoptosis 2007;12:1543-1568.

$\checkmark 2$ Karnak D, Xu L: Chemosensitization of prostate cancer by modulating Bcl-2 family proteins. Curr Drug Targets 2010;11:699-707.

-3 Löhr JM: Medical treatment of pancreatic cancer. Expert Rev Anticancer Ther 2007;7: 533-544.

4 Claude L, Mornex F: Chemoradiation in pancreatic carcinoma. Cancer Radiother 2003;7:254-265.

$>5$ Yeh JJ, Der CJ: Targeting signal transduction in pancreatic cancer treatment. Expert Opin Ther Targets 2007;11:673-694.

6 Hamacher R, Schmid RM, Saur D, Schneider G: Apoptotic pathways in pancreatic ductal adenocarcinoma. Mol Cancer 2008;7:64-70.

$>7$ Sheikh R, Walsh N, Clynes M, O’Connor R, McDermott R: Challenges of drug resistance in the management of pancreatic cancer. Expert Rev Anticancer Ther 2010;10:16471661.

$>8$ Roy SK, Srivastava RK, Shankar S: Inhibition of PI3K/AKT and MAPK/ERK pathways causes activation of FOXO transcription factor, leading to cell cycle arrest and apoptosis in pancreatic cancer. J Mol Signal 2010;5:10.

$>9$ Danial NN: BCL-2 family proteins: critical checkpoints of apoptotic cell death. Clin Cancer Res 2007;13:7254-7263.

10 Roset R, Ortet L, Gil-Gomez G: Role of Bcl-2 family members on apoptosis: what we have learned from knock-out mice. Front Biosci 2007;12:4722-4730.

$\checkmark 11$ Youle RJ, Strasser A: The BCL-2 protein family: opposing activities that mediate cell death. Nat Rev Mol Cell Biol 2008;9:47-59.

$\checkmark 12$ Breckenridge DG, Xue D: Regulation of mitochondrial membrane permeabilization by BCL-2 family proteins and caspases. Curr Opin Cell Biol 2004; 16:647-652.

$>13$ Tsujimoto Y: Cell death regulation by the Bcl-2 protein family in the mitochondria. J Cell Physiol 2003;195:158-167.

$\checkmark 14$ Hattori T, Ookawa N, Fujita R, Fukuchi K: Heterodimerization of $\mathrm{Bcl}-2$ and $\mathrm{Bcl}-\mathrm{X}(\mathrm{L})$ with Bax and Bad in colorectal cancer. Acta Oncol 2000;39:495-500.
15 Gianni M, Ponzanelli I, Mologni L, Reichert U, Rambaldi A, Terao M, Garattini E: Retinoid-dependent growth inhibition, differentiation and apoptosis in acute promyelocytic leukemia cells: expression and activation of caspases. Cell Death Differ 2000;7:447-460.

16 Pettersson F, Dalgleish AG, Bissonnette RP, Colston KW: Retinoids cause apoptosis in pancreatic cancer cells via activation of RAR-gamma and altered expression of Bcl2/Bax. Br J Cancer 2002;87:555-561.

17 Casneuf VF, Fonteyne P, Van Damme N: Expression of SGLT1, Bcl-2 and p53 in primary pancreatic cancer related to survival. Cancer Invest 2008;26:852-859.

18 Hashimoto K, Nio Y, Koike M, Itakura M, Yano S, Higami T, Maruyama R: Expression of retinoblastoma and p53 pathway-related proteins in resectable invasive ductal carcinoma of the pancreas: potential cooperative effects on clinical outcome. Anticancer Res 2005;25:1361-1368.

19 Geng Y, Walls KC, Ghosh AP, Akhtar RS, Klocke BJ, Roth KA: Cytoplasmic p53 and activated Bax regulate p53-dependent, transcription-independent neural precursor cell apoptosis. J Histochem Cytochem 2010;58: 265-275.

20 Wu Y, Mehew JW, Heckman CA, Arcinas M, Boxer LM: Negative regulation of bcl-2 expression by $\mathrm{p} 53$ in hematopoietic cells. Oncogene 2001;20:240-251.

21 Slebos RJ, Hoppin JA, Tolbert PE, Holly EA, Brock JW, Zhang RH, Bracci PM, Foley J, Stockton P, McGregor LM, Flake GP, Taylor JA: K-ras and p53 in pancreatic cancer: association with medical history, histopathology, and environmental exposures in a population-based study. Cancer Epidemiol Biomarkers Prev 2000;9:1223-1232.

22 Horiuchi H, Kawamata H, Omotehara F, Fujii S, Fujimori T, Kuroda Y: Negative immunohistochemical staining of p53 protein does not always reflect wild-type p53 gene in cancer cells. J Gastroenterol 2004;39:801803.

23 Martens U, Stenius U: Immunohistochemical detection of induced expression of wildtype 553 tumor suppressor protein in the livers of rats treated with diethylnitrosamine. Histochem J 1999;31:75-78.
24 van Gijssel HE, van Gijlswijk RP, de Haas RR, Stark C, Mulder GJ, Meerman JH: Immunohistochemical visualization of wild-type p53 protein in paraffin-embedded rat liver using tyramide amplification: zonal hepatic distribution of p53 protein after N-hydroxy-2acetylaminofluorene administration. Carcinogenesis 1998;19:219-222.

25 Barakat K, Mane J, Friesen D, Tuszynski J: Ensemble-based virtual screening reveals dual-inhibitors for the p53-MDM2/MDMX interactions. J Mol Graph Model 2010;28: 555-568.

26 Krepischi-Santos AC, Rajan D, Temple IK, Shrubb V, Crolla JA, Huang S, Beal S, Otto PA, Carter NP, Vianna-Morgante AM, Rosenberg C: Constitutional haploinsufficiency of tumor suppressor genes in mentally retarded patients with microdeletions in 17p13.1. Cytogenet Genome Res 2009;125: 1-7.

-27 Greiner TC, Dasgupta C, Ho VV, Weisenburger DD, Smith LM, Lynch JC, Vose JM, Fu K, Armitage JO, Braziel RM, Campo E, Delabie J, Gascoyne RD, Jaffe ES, Muller-Hermelink HK, Ott G, Rosenwald A, Staudt LM, Im MY, Karaman MW, Pike BL, Chan WC, Hacia JG: Mutation and genomic deletion status of ataxia telangiectasia mutated (ATM) and p53 confer specific gene expression profiles in mantle cell lymphoma. Proc Natl Acad Sci USA 2006;103:2352-2357.

28 Slee EA, O'Connor DJ, Lu X: To die or not to die: how does p53 decide? Oncogene 2004; 23:2809-2818.

29 Clarke AR, Purdie CA, Harrison DJ: Thymocyte apoptosis induced by p53-dependent and independent pathways. Nature 1993; 362:849-852.

30 Sato Y, Nio Y, Song MM: p53 protein expression as prognostic factor in human pancreatic cancer. Anticancer Res 1997;17:27792788.

31 Dergham ST, Dugan MC, Joshi US: The clinical significance of p21(WAF1/CIP-1) and p53 expression in pancreatic adenocarcinoma. Cancer 2002;80:372-381.

32 Miyashita T, Krajewski S, Krajewska M: Tumor suppressor $\mathrm{p} 53$ is a regulator of bcl-2 and bax gene expression in vitro and in vivo. Oncogene 1994;9:1799-1805. 